\title{
A review on thermal management of lithium- ion batteries for electric vehicles
}

\author{
Xinghui Zhang ${ }^{\mathrm{a}}$, Zhao $\mathrm{Li}^{\mathrm{a}}$, Lingai Luo ${ }^{\mathrm{b}, *}$, Yilin Fan ${ }^{\mathrm{b}}$, Zhengyu $\mathrm{Du}^{\mathrm{a}}$ \\ ${ }^{a}$ College of Civil Engineering, Taiyuan University of Technology, Taiyuan, Shanxi, 030024, PR \\ China \\ b Université de Nantes, CNRS, Laboratoire de thermique et énergie de Nantes, LTeN, UMR 6607, \\ F-44000 Nantes, France \\ Corresponding author: Lingai LUO, Lingailuo@univ-nantes.fr
}

\begin{abstract}
In recent years, energy and environmental issues have become more and more prominent, and electric vehicles powered by lithium-ion battery have shown great potential and advantages in alleviating these issues. Compared with other batteries, lithium-ion batteries have the advantages of high specific energy, high energy density, long endurance, low self-discharge and long shelf life. However, temperature of the battery has become one of the most important parameters to be handled properly for the development and propagation of lithium-ion battery electric vehicles. Both the higher and lower temperature environments will seriously affect the battery capacity and the service life. Under high temperature environment, lithium-ion batteries may produce thermal runaway, resulting in short circuit, combustion, explosion and other safety problems. Lithium dendrites may appear in lithium-ion batteries at low temperature, causing short circuit, failure to start and other operational faults. In this paper, the used thermal management methods of lithium-ion batteries are introduced and their advantages and disadvantages are discussed and compared. At the same time, the prospect of future development is put forward.
\end{abstract}

Keywords: Lithium-ion battery; Battery thermal management system; Temperature Uniformity; Electric vehicles. 


\section{Introduction}

With the rapid development of China's economy, people's living standards are also improving, and private cars have gradually entered the family. However, traditional fossil fuel resources such as oil are limited, and their combustion will emit greenhouse gases (GHG) and harmful substances ${ }^{[1,}$ ${ }^{2]}$ and affect the environment and climate ${ }^{[3]}$. A series of problems, such as energy shortage, environmental pollution and climate warming, brought by the traditional petrol-powered vehicles with oil or diesel as the main fuel, have also become the public concerns ${ }^{[4]}$. The transportation sector (fuel-powered automobiles) is one of the major consumers of fossil energies and thereby contributing a great part to the air pollutions and the GHG emissions. According to the 2017 China Motor Vehicle Environmental Management Annual Report ${ }^{[5]}$, the total emission of four pollutants (CO, NOx, carbureted hydrogen and particulate matter) from motor vehicles in China was 42.597 million tons. Facing these issues, a technology revolution of vehicles has quietly been emerging since the last century in Europe and now sweeping the world. Firstly, many countries have announced plans to ban the sale of petrol-powered vehicles from 10 to 40 years onwards. Secondly, cleaner and more environmentally friendly new energy vehicles also appear in the public's view, providing alternative choices for the majority of consumers. Electric vehicles (EVs) are the representative of clean and environmentally friendly vehicles.

\subsection{A short history of EVs}

The origin of EVs can be traced back to the 1830s. Thomas Davenport of the United States built the world's first tricycle powered by a non-rechargeable dry battery. In the 1880s, Gustave Trouve in France built the world's first rechargeable lead-acid battery-powered tricycle ${ }^{[6]}$. Frank Sprague designed and produced trams ${ }^{[7]}$. The iron and nickel battery invented by Thomas Edison provided the impetus for the development of EVs. At the end of the 19th century, many American and British companies began producing EVs. At the beginning of the 20th century, there were more than 30,000 EVs in operation in the United States ${ }^{[8]}$, playing an important role in private transportation. At that time, EVs were a symbol of wealth, a vehicle for financial titans. After nearly a century of development, EVs have been driven by chemical power sources, from lead-acid batteries to nickel-metal hydride batteries and nickel-cadmium batteries. However, these batteries become more and more inadequate to meet the power requirements of pure EVs due to some technical constraints, such as battery volume, battery working environment and battery charging time. Combined with the rapid development of traditional diesel automobiles, the available global oil resources and other resources exploration and development, EVs were at a disadvantage in application.

In the 21 st century, with the rapid development of economy and human society, the demand for energy is fast increasing. How to reduce the energy consumption of the transport sector is a matter of concern. Electric cars are once again on the scene. EVs have significant advantages in energy conservation, emission reduction and environmental protection. The popularization and application of EVs are of great significance for alleviating environmental pollution, solving the oil crisis, ensuring national energy security and realizing the sustainable development of society and economy. 


\subsection{Batteries for EVs}

With the continuous breakthrough of key technologies for EVs and the improvement of infrastructure, countries all over the world have joined the ranks of seizing the technology and market of EVs. There are four main types of EVs: hybrid electric vehicle (HEV), battery electric vehicle (BEV), fuel cell electric vehicle (FCEV) and other new energy EVs. The development of energy storage technologies has greatly accelerated the battery-driven trend in the automobile industry. EVs have three core components: power sources, motor and electronic control system. From the perspective of global new energy vehicle development, its power sources mainly include lithium-ion batteries (LIBs), nickel metal hydride batteries, fuel cells, lead-acid batteries, supercapacitors and so on. The working state of the power sources is closely related to temperature. LIBs have shown great potential in the application of EVs at room temperature. It has the advantages of high specific energy, high energy density ${ }^{[9,10]}$, long service life, low self-discharge ${ }^{[11]}$ and long shelf life ${ }^{[12]}$. But for LIBs to be widely used in EVs, safety ${ }^{[13]}$, cost, energy efficiency, charging devices and other issues need to be considered. Among various influencing factors, the operating temperature plays an important role on the performance, life and safety of $\operatorname{LIBs}^{[14]}$. At too low or too high temperature, the charge-discharge performance of LIB is still a big problem ${ }^{[15]}$.

Therefore, in view of the complex thermal characteristics of EVs under different external environmental conditions and driving conditions, it is necessary to develop the battery thermal management system (BTMS) ${ }^{[16]}$, which plays a decisive role in the future development of EVs.

\subsection{Objectives of this review paper}

At present, there are a lot of scholars studying the temperature management of EVs working in harsh environments. This topic has received increasing research attention, indicated by the significantly increasing number of yearly publications since 2000 (Fig. 1).

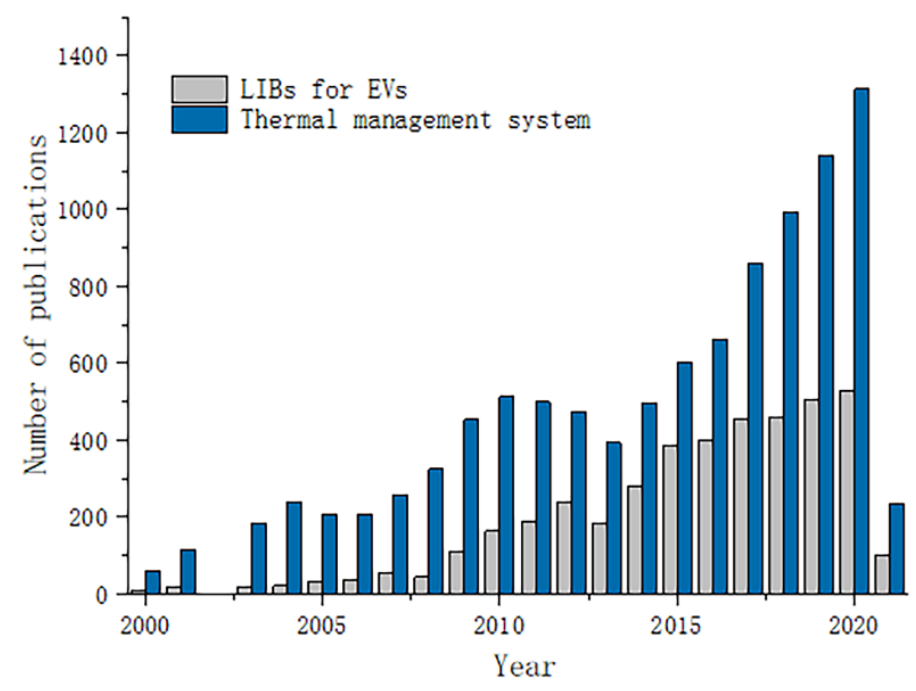

Fig. 1. Number of publications on the LIBs for EVs (source: Scopus; keyword: LIBs for EVs, thermal management system; date: 20 January 2021) 
Reviews papers related to LIBs for EVs have also been published. Raijmakers et al. ${ }^{[17]}$ have summarized various methods of temperature indication of LIBs and briefly introduced the working principle of LIBs. Xie et al. ${ }^{[18,19]}$ have studied the thermal simulation of LIBs and proposed a variety of electrothermal models to provide support for the thermal management of LIBs. Wu et al. ${ }^{[20]}$ and Vidal et al. ${ }^{[21]}$ have reviewed the heating technology of LIBs in cold weather. Jaguemont and Mierlo ${ }^{[22]}$ have reviewed the current situation of BTMS and systematically introduced traditional cooling systems. Specifically, Landini et al. ${ }^{[23]}$ and Chen et al. ${ }^{[24]}$ have analyzed and reviewed the applications of phase change materials (PCMs) in the thermal management of LIBs-EVs. Solyali and Akinlabi ${ }^{[25]}$ have focused on the analysis of the air-cooled BTMS for EVs. Choudhari et al. ${ }^{[26]}$ have reviewed temperature control systems for different cooling technologies such as air convection, liquid convection, PCMs and their combinations. However, most of the reviews only focus on the heating or cooling of LIBs while a comprehensive overview of the thermal management for LIBsEVs is still lacking.

Therefore, the main objective of this review paper is to summarize the efforts made by various researchers in the development of EV's BTMS using electric heating, air heating/cooling, liquid heating/cooling, and PCMs heating/cooling, as well as their advantages and challenges. The paper starts with a brief overview of the working principle of LIBs, the heat generation principles and possible consequences, providing the basic battery functioning knowledge to the readers. Then, various heating and cooling methods of LIBs under low and high temperature conditions are systematically summarized. Finally, the prospect of BTMS for lithium-ion EVs in the future is put forward.

The rest of the paper is organized as follows. Section 2 begins with the hazardous consequences of LIBs due to harsh temperatures. Section 3 introduces the common heating methods of LIBs. Section 4 describes the common cooling methods of LIBs. In section 5, the main conclusions are summarized and some prospects are proposed.

\section{Temperature: the key factor impacting the performance of LIBs}

A LIB consists of a positive electrode, a negative electrode, an electrolyte, a membrane through which only lithium-ions can pass freely, and a battery shell. LIBs use carbon material as the negative electrode and lithium-containing compounds as the positive electrode, such as $\mathrm{LiFePO}_{4}, \mathrm{LiMn}_{2} \mathrm{O}_{4}$ and $\mathrm{Li}(\mathrm{NiCoMn}) \mathrm{O}_{2}$. LIBs work mainly by moving lithium-ions between the positive and negative poles. For the discharging process, the lithium-ions detach from the negative electrode and pass through the electrolyte to penetrate into the positive electrode. The charging process is the reverse operation. Charging and discharging of LIBs involve thereby an electrochemical reaction, which takes time and is accompanied by the conversion of energy and heat. The electrode reaction in charge and discharge process is illustrated by an example of lithium iron phosphate battery[27].

The positive electrode reaction equation for the discharging of LIB is:

$$
\mathrm{LiFeO}_{4} \rightarrow \mathrm{Li}_{1-x} \mathrm{FePO}_{4}+x \mathrm{Li}^{+}+x e^{-}
$$

The negative reaction equation is:

$$
6 C+x L i^{+}+x e^{-} \rightarrow L i_{x} C_{6}
$$

The overall reaction equation is:

$$
\mathrm{Li}_{x} \mathrm{C}_{6}+\mathrm{Li}_{1-x} \mathrm{FePO}_{4} \rightarrow 6 \mathrm{C}+\mathrm{LiFeO}_{4}
$$

There are four main sources of heat inside a battery ${ }^{[28]}$ : the reaction heat from a reversible 
reaction; the by-reaction heat generated by electrolyte decomposition during overcharging or overdischarge; joule heat due to the internal resistance of the cell due to the Joule effect; and the heat of polarization generated by the polarization reaction. The larger the discharge current of the battery, the smaller the discharge capacity and the faster the voltage drop. When the charging current increases, the charging speed increases, and the more heat a battery generates. Based on the literature survey, the recommended operating temperature ranges of the battery pack are closely overlapping. The common operating temperature of LIBs is usually between $15^{\circ} \mathrm{C}$ and $40^{\circ} \mathrm{C}[29,30]$. Adapted temperature is an important guarantee for the efficient operation of LIBs and also one of the key factors to improve the performance of the EV.

\subsection{LIBs at low temperature}

The performance of LIBs can be problematic at low temperatures (e.g., $\left.<15{ }^{\circ} \mathrm{C}\right)$. Both the charging and discharging performance will be affected because the electrochemical reaction cannot be carried out normally ${ }^{[31]}$. When the temperature is too low, the diffusion rate of lithium-ions in the electrolyte decreases seriously due to the increase of electrolyte viscosity, resulting in significant increase of the internal resistance. The number of lithium-ions participating in the reaction decreases, which will directly affects the electricity storage and release, leading to the attenuation of battery capacity and power characteristics ${ }^{[32]}$. Under extreme conditions, the electrolyte freezes, preventing the battery from discharging and the car from starting. For the charging of LIBs at low temperature, lithium dendrites may pierce the film, forming an internal short circuit and threatening the safety of use $^{[33]}$. Fig. 2 shows the relationship between charging capacity and charging voltage at different temperatures. In constant current charging, the charging voltage increases continuously and rapidly to the cut-off voltage as the temperature drops. Studies show that LIBs can only be charged at $10{ }^{\circ} \mathrm{C}$ with $10 \mathrm{~A}$ constant current charging capacity of only $60 \%$ of the rated capacity ${ }^{[34]}$. This irreversible capacity reduction is also related to the number of battery uses. Finally, significant temperature difference may occur in different areas (cells) of the battery pack. The uneven temperature distribution inside the battery pack will cause local degradation ${ }^{[35]}$, accelerating the battery aging and reducing the battery lifetime.

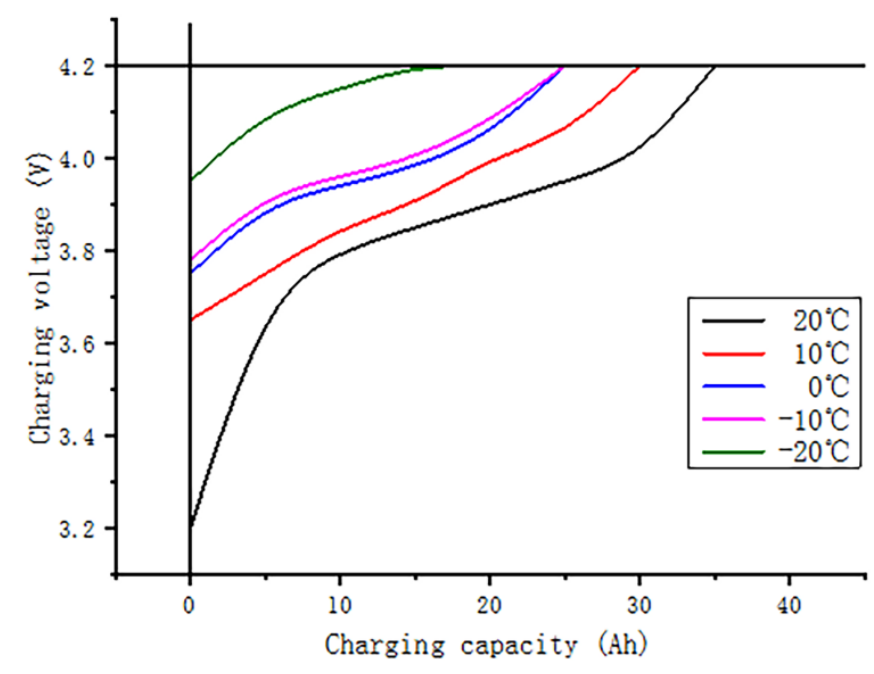

Fig. 2. Charging curve at $10 \mathrm{~A}$ constant current and constant voltage at different temperature 


\subsection{LIBs at high temperature}

LIBs can also have performance problems at high temperatures (e.g., $\left.>40{ }^{\circ} \mathrm{C}\right)^{[36,37]}$. On one hand, lithium is chemically very reactive and burns easily. LIB pack is composed of many single LIBs in series or in parallel, so that the heat generated by the electrochemical reaction of the battery itself cannot be released in time due to the high environment temperature when the battery pack undergoes charging or discharging. A single battery cell may be overheated, resulting in the combustion, the explosion, or the escape of toxic gases (e.g., $\left.\mathrm{CO}, \mathrm{C}_{2} \mathrm{H}_{4}, \mathrm{H}_{2} \mathrm{~S}, \mathrm{HF}\right)^{[38,39]}$. Moreover, the short circuit may occur at high temperature due to the complicated internal power circuit structure of LIB pack ${ }^{[40-42]}$. On the other hand, high temperatures also affect the capacity of LIBs. Studies have shown that LIBs lose nearly $70 \%$ of their capacity after 500 cycles of discharging at $55{ }^{\circ} \mathrm{C}^{[43]}$. This effect greatly shortens the life of $\mathrm{LIBs}^{[44]}$, not to mention the runaway heat that seriously threatens the human life.

All these problems of LIBs in harsh weather due to poor heating or cooling will seriously hinder the massive deployment and propagation of EVs. Finding appropriate thermal management solutions for better temperature control of LIB pack is therefore essential. The common heating and cooling methods of LIBs are described in the following sections.

\section{Heating methods for LIBs}

In order to augment the performance of EV LIBs at low temperature, the LIBs must be heated and insulated. According to different heating forms, the heating methods for LIBs can be divided into the following categories: electric heating, air heating, liquid heating, PCM heating, and other heating methods (such as Peltier effect and heat pipe).

\subsection{Electrical heating}

At low temperature, the viscosity of electrolyte and the internal resistance increase. Taking advantage of this property by sending an electric current through a resistance, the resulting joule effect will heat the LIBs up and make them work.

Li et al. ${ }^{[45]}$ have improved the performance of LIB at low temperature by heating an aluminum sheet with positive temperature coefficient (PTC) resistance wire winding. $\mathrm{LiMn}_{2} \mathrm{O}_{4}$ power battery with nominal voltage of $3.7 \mathrm{~V}$ and capacity of $35 \mathrm{Ah}$ was selected as the research object. It was placed at $-40^{\circ} \mathrm{C}$ for 10 hours. The battery is charged by $1 / 3 \mathrm{C}$ constant current and constant voltage at normal temperature. After charging, the battery was placed at $20{ }^{\circ} \mathrm{C}$ and $-20{ }^{\circ} \mathrm{C}$ respectively to discharge at a certain rate until the discharge voltage of a single battery reached $3 \mathrm{~V}$. Both simulation and experimental results indicated that the PTC heating method, can greatly improve the performance of battery at low temperature.

Lei et al. ${ }^{[46]}$ have proposed the method of heating the battery by placing two wide wire metal films on the two largest surfaces of the battery. One side of the wide wire metal film was a rectangular copper film, and the other side was a certain width of continuous copper wire. A battery

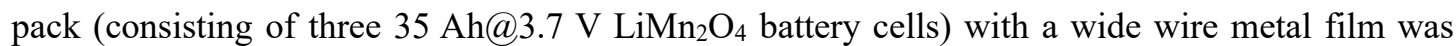
placed in the battery box. The battery box was placed at $-40{ }^{\circ} \mathrm{C}$ for $5-8$ hours to achieve the thermal 
balance, and then the low-temperature discharge performance was tested. Heating at $-40{ }^{\circ} \mathrm{C}$ and 120 W for 15 minutes was shown to be equivalent to charging and discharging at $0{ }^{\circ} \mathrm{C}$.

Jaguemont et al..$^{[4]}$ has proposed an effective LIB model suitable for thermal management of HEVs. The cells were placed in a climate chamber to recreate the climate at $-20^{\circ} \mathrm{C},-10^{\circ} \mathrm{C}, 0.0^{\circ} \mathrm{C}$, and $+25{ }^{\circ} \mathrm{C}$ respectively. Experimental results showed that the improved electrothermal model worked well at low temperatures. Whether the high current value could accelerate the cell degeneration or not remained to be studied. The model was also applicable for the battery pack of HEVs.

Jin et al. ${ }^{[48]}$ have put forward the PTC self-heating method of battery and conducted experimental tests. The slotted aluminum plate was placed between the two batteries and the PTC resistance belt was embedded into the slotted aluminum plate. The heat generated by the PTC can be quickly transferred to the battery for its heating in cold weather e.g., $-36.4^{\circ} \mathrm{C}$. After the heating for 34.2 minutes, the average temperature of the battery pack raised to $-20.7^{\circ} \mathrm{C}$. Nevertheless, the PTC self-heating device would increase the weight of the battery body and make the battery structure more complex. Further improvement is thus needed.

Lei et al. ${ }^{[49]}$ have established a 3D finite element model and analyzed the temperature gradient of self-heating lithium-ion battery (SHLB). The intermittent SHLB heating method has been put forward. Their experimental results indicated that 0.1 VS 0.3 intermittent SHLB heating method (heating for $0.1 \mathrm{~s}$ and stopping heating for $0.3 \mathrm{~s}$ ) could heat the LIBs well. However, the optimal interval time remained to be further studied.

Jiang et al. ${ }^{[50]}$ have proposed the coupling of direct current and alternating current to heat LIBs. Firstly, the LIB pack was placed in a climate box at $-20{ }^{\circ} \mathrm{C}$ for more than 10 hours to simulate the working environment of the battery in winter conditions. Then, direct current and alternating current generated by the soft switch resonant circuit were used to heat the battery. After 600 times of repeated experiments, the best heating effect was found to be achieved with AC frequency at about $754 \mathrm{~Hz}$. However, the optimal ratio between the DC and AC still needs to be determined. How to maximize the heat production rate while reducing the risk of lithium-ion deposition is another research direction.

Yang et al. ${ }^{[51]}$ have proposed the concept of a full climate LIBs, as shown in Fig. 3. In addition to the usual anode, cathode and electrolyte, an activation terminal consisting of 50 micron nickel foil and insulating layer was included. The temperature of the battery pack was controlled by switching between the activation terminal and the negative terminal ${ }^{[52]}$, and the heating process was monitored and characterized by the infrared thermography ${ }^{[53]}$. An electric current was sent to pass through the nickel foil so as to generate heat. Compared with some conventional electric heating methods such as PTC, the power of the external heater must be increased in order to accelerate the heating. However, for large-sized thick batteries, local overheating may occur. At the same time, in the actual operation of EVs, the output current of the battery depends on the power demand of the driver. In this regard, it is unrealistic to heat the traditional battery with high current discharge ${ }^{[54,55]}$. 

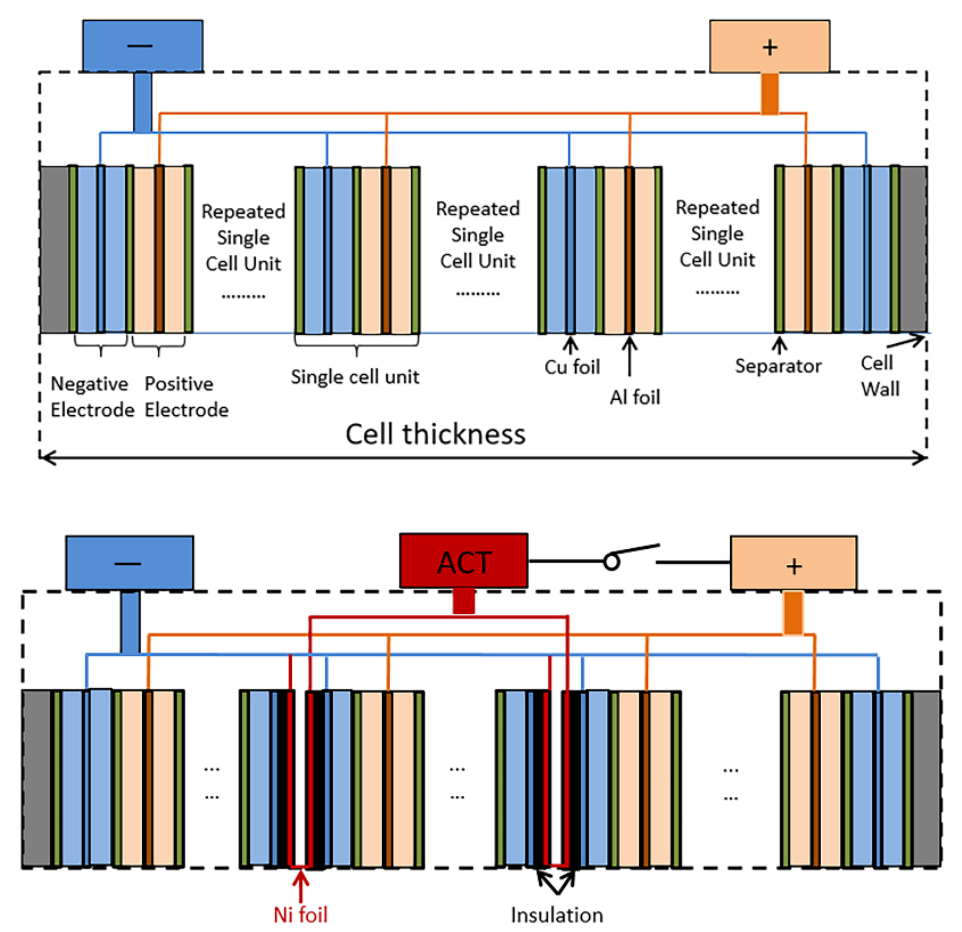

Fig. 3. Schematic illustration of a conventional Li-ion cell and a self-heating Li-ion battery with multiple Ni foils inserted ${ }^{[51]}$

$\mathrm{Ji}$ and Wang ${ }^{[56]}$ have proposed a method of pulse mutual heating. The entire battery pack was divided into two equal sized packs, one undergone discharging while the other charged. Their experimental results showed that the LIBs could be heated from $-20^{\circ} \mathrm{C}$ to $20^{\circ} \mathrm{C}$, with a capacity loss of only $5 \%$.

\subsection{Air heating}

The principle of the air heating method is shown in Fig. 4. The temperature of the electric heating wire is firstly raised by the power supply from the battery. Then the electric heating wire at high temperature heats up the surrounding air by convection. The hot air enters into the battery box by the fan and exchanges heat with the battery monomer to heat the low-temperature battery to the appropriate temperature. 


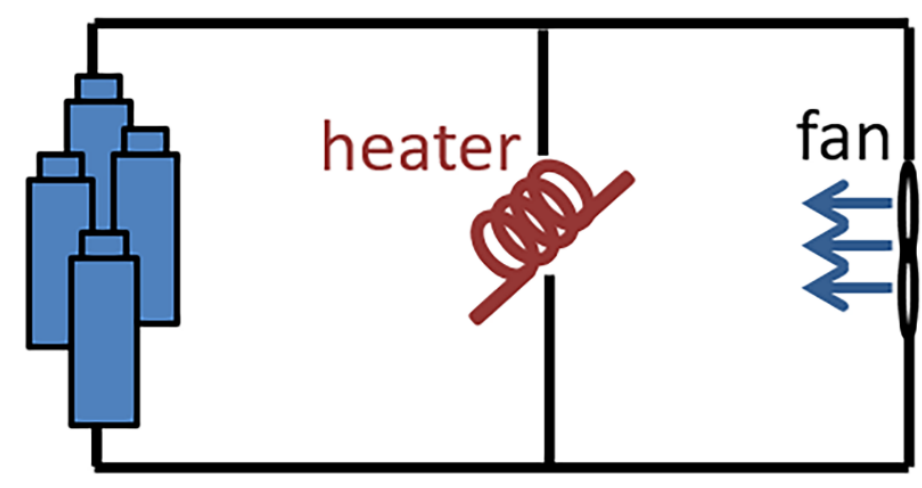

Fig. 4. Principle of air heating

Ji and Wang ${ }^{[56]}$ have proposed a convection heating strategy, as shown in Fig. 5. External heating used the power output of the battery to convert electrical energy into heat through the resistance heater. The fan generated convection air flow to enhance the heat transfer between the heater and the air, and from the air to the battery. The advantage of the convective heating strategy lies in its high efficiency, but the heat conduction inside the battery pack may become a limiting factor due to the thickness of the battery cell, leading to a larger temperature gradient inside the battery.

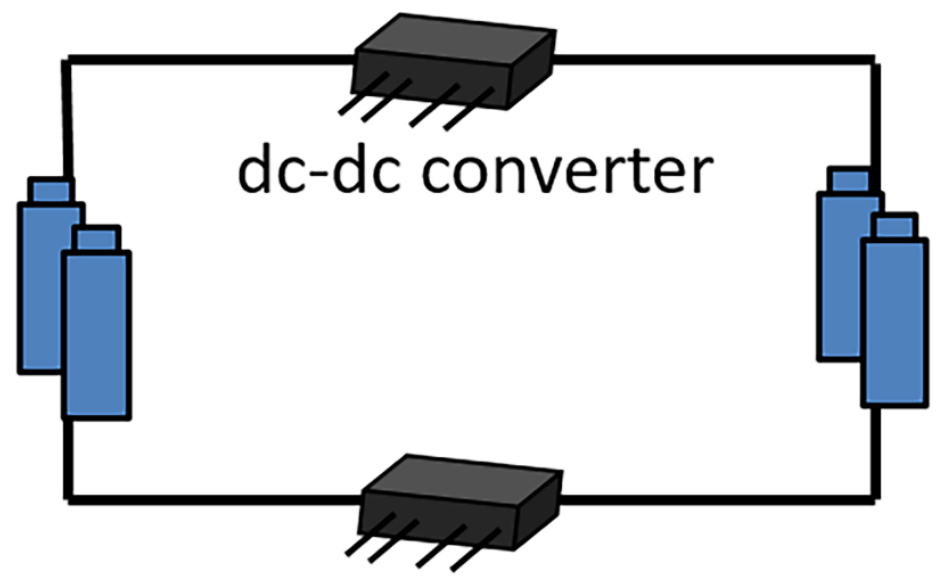

Fig. 5. Convection heating strategy ${ }^{[56]}$

Mahamud and Park ${ }^{[57]}$ have proposed a new method for thermal management of cylindrical LIBs by means of reciprocating airflow. Two-dimensional computational fluid dynamics (CFD) model, lumped capacitive heat model and flow network model were developed and compared. The experimental results showed that the network model was in good agreement with the 2D CFD results, which could effectively manage the temperature of the battery. The shorter the reciprocating period, the lower the temperature difference and maximum unit temperature of the system. The influence of different battery spacing on the thermal management effect remained to be further studied. 


\subsection{Liquid heating}

Similar to air heating, the electric heating wire is firstly heated by a power source to raise its temperature, as shown in Fig. 6. The high-temperature electric wire heats then a liquid, which flows between the heating wire and the battery monomer through reserved flow channels to heat the lowtemperature battery up to an appropriate temperature. The commonly used heat transfer mediums include water, oil, glycol, acetone and so on ${ }^{[35]}$. Compared with air heating, liquid heating has great advantages due to its higher specific heat capacity and higher heat transfer coefficient. The battery pack could therefore be more compact. It must be pointed out that the liquid heating also has some technological barriers to overcome, such as the liquid leakage problem and the design of the efficient flow network ${ }^{[58]}$.

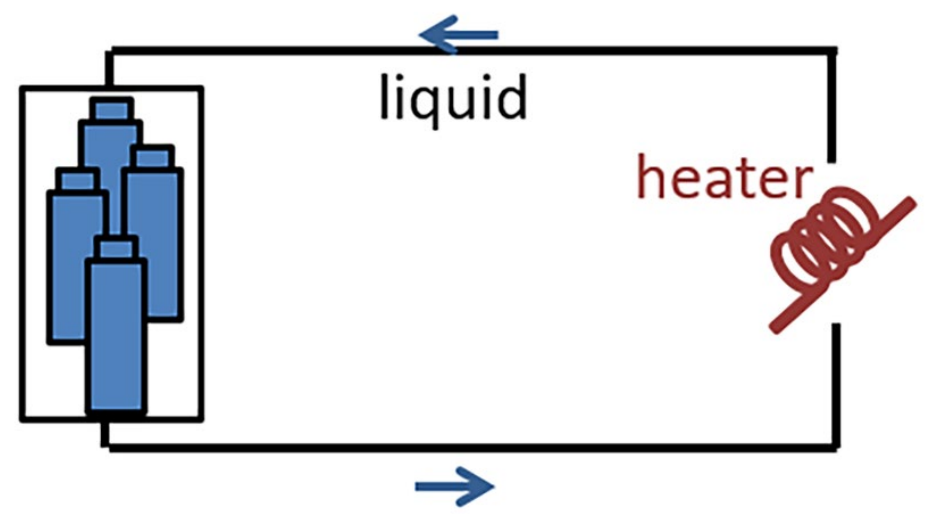

Fig. 6. Schematic of liquid heating

Nelson et al ${ }^{[59]}$ have proposed a method of heating or cooling the battery with silicone variable pressure fluid, which is a better heat transfer fluid than air. Its thermal conductivity is greater than air, and its heat capacity per unit volume is also higher than air. However, due to the temperature difference between the heating and cooling battery, the size design of fluid channel is particularly important in order to realize the whole process of summer cooling and winter heating simultaneously.

\subsection{PCM heating}

PCMs include hydrated salts, stearic acid, polyethylene glycol, paraffin, graphene and phase change composites based on them. As shown in Fig. 7, PCMs can be filled inside a framework to form a new kind of composite phase change material (CPCM) in a modular manner. During battery discharge, the CPCM absorbs the heat released by the battery, rapidly reducing the battery temperature. 


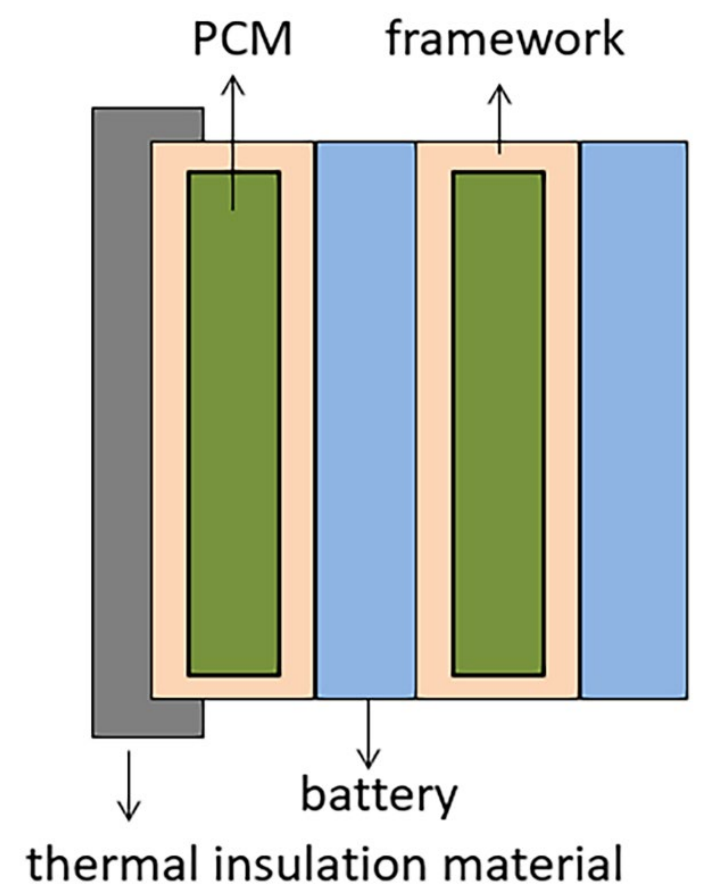

Fig. 7. Schematic diagrams of the CPCM-based battery pack

Zhang et al. ${ }^{[14]}$ have proposed using pentadecane $\left(\mathrm{C}_{15} \mathrm{H}_{31}\right)$ as microencapsulated PCM slurry for battery heating. Phase change slurry cycle having high latent heat capacity is a commonly used heat transfer medium in the heat transfer process. Microencapsulated PCM slurry can be used for heating applications of EVs. The melting temperature of pentadecane is $9.9^{\circ} \mathrm{C}$. Their experimental results showed that the active heating system could keep the temperature of the battery box above $0{ }^{\circ} \mathrm{C}$, and the battery could work at $5-10{ }^{\circ} \mathrm{C}$. Octadecane and pentadecane are used in combination to meet summer and winter conditions respectively.

\subsection{Other methods}

Other methods have been used to heat LIBs, by using the Peltier effect elements or the heat pipe.

The Peltier effect or the second thermoelectric effect is known as two different semiconductors formed into a cycle. After passing through the direct current, the connection of two conductors produces heat absorption or exothermic phenomenon, forming high and low temperature areas. The Peltier element based on the Peltier effect can transfer heat from the higher end of the free electron count to the lower end. The direction of heat transfer can be changed by changing the direction of current. Troxler et al. ${ }^{[60]}$ have used the Peltier elements to control the temperature of LIBs, as shown in Fig. 8. One end of the Peltier element was in contact with the battery, and the other end was connected with a water cooled heat sink. The battery was heated by the movement of free electrons within the Peltier elements. In order to make the heating effect more uniform, copper plate was inserted between the Peltier element and the battery. Experiments were carried out in the range of $-13{ }^{\circ} \mathrm{C}$ to $55^{\circ} \mathrm{C}$. Since the Peltier effect requires a large temperature gradient, how to improve its thermal efficiency is the focus of the future research. 


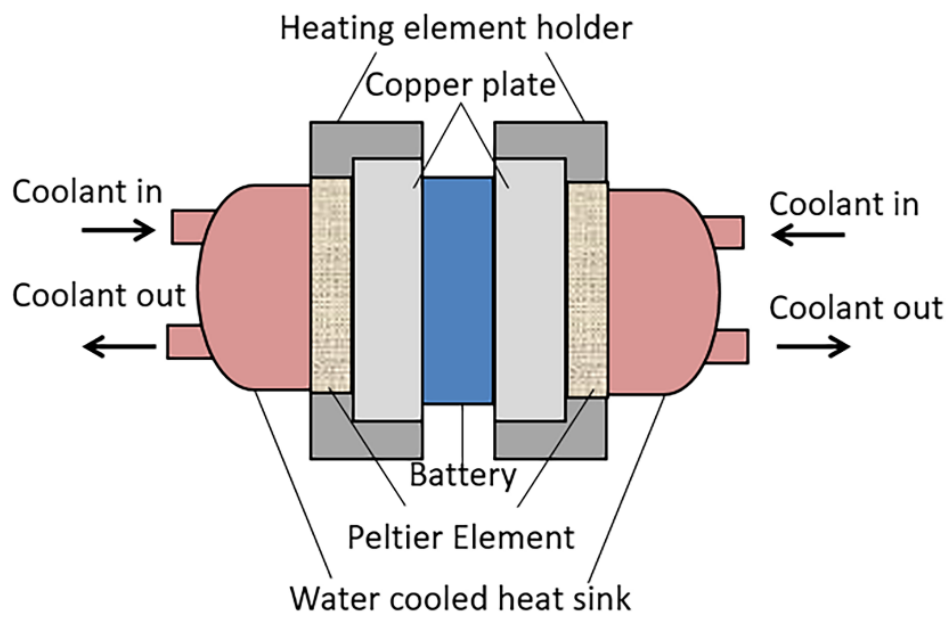

Fig. 8. Structure diagram of Peltier effect heating ${ }^{[60]}$

Heat pumps and heat pipes are also used to heat LIBs. Parekh ${ }^{[61]}$ has studied three methods of thermal management for LIBs, including the simple electric heating, the heat pipe heating and the composite solid-state thermoelectric heat pump and heat pipe heating. The operating conditions of the battery from $-10{ }^{\circ} \mathrm{C}$ to $10{ }^{\circ} \mathrm{C}$ have been tested. The heating effect of composite solid-state thermoelectric heat pump and heat pipe system was found to be better than that of simple electric heating or heat pipe heating. The heat pipe could make the heat distribution more uniform. However, the operating temperature range of the battery is limited. The design of thermal resistance, bypass flow and inefficient spacing still needs further study.

\subsection{Short summary}

\section{Table 1}

Short summary of different heating methods

\begin{tabular}{|c|c|c|c|c|c|}
\hline Author & Method & Condition & $\begin{array}{l}\text { Heat- } \\
\text { up } \\
\text { time }\end{array}$ & Result & Notes \\
\hline Li et al. ${ }^{[45]}$ & $\begin{array}{c}\text { battery cell, } \\
\text { PTC resistance } \\
\text { wire winding }\end{array}$ & $35 \mathrm{~W},-40^{\circ} \mathrm{C}$ & $\begin{array}{l}25 \\
\min \end{array}$ & $0{ }^{\circ} \mathrm{C}$ & $\begin{array}{c}\text { poor temperature } \\
\text { uniformity }\end{array}$ \\
\hline Lei et al. ${ }^{[46]}$ & $\begin{array}{c}\text { battery pack, } \\
\text { wide wire metal } \\
\text { film }\end{array}$ & $90 \mathrm{~W},-40^{\circ} \mathrm{C}$ & $\begin{array}{c}15 \\
\min \end{array}$ & $\begin{array}{c}\text { the same as } \\
\text { working at } \\
0^{\circ} \mathrm{C}\end{array}$ & $\begin{array}{c}\text { the structure of } \\
\text { the heating device } \\
\text { is simple }\end{array}$ \\
\hline \multirow[t]{2}{*}{$\begin{array}{c}\text { Jaguemont } \\
\text { et al. }{ }^{[47]}\end{array}$} & $\begin{array}{l}\text { battery cell, } \\
\text { high current } \\
\text { heating }\end{array}$ & $300 \mathrm{~A},-10^{\circ} \mathrm{C}$ & $\begin{array}{l}83.3 \\
\min \\
16.7 \\
\min \end{array}$ & $15^{\circ} \mathrm{C}$ & \multirow[t]{2}{*}{$\begin{array}{c}\text { accelerated } \\
\text { degradation due } \\
\text { to high current }\end{array}$} \\
\hline & & $300 \mathrm{~A}, 0^{\circ} \mathrm{C}$ & $\begin{array}{l}16.7 \\
\min \end{array}$ & $25^{\circ} \mathrm{C}$ & \\
\hline Jin et al. ${ }^{[48]}$ & battery pack, & $190 \mathrm{~V},-$ & 34.2 & $-20.7^{\circ} \mathrm{C}$ & slower \\
\hline
\end{tabular}




\begin{tabular}{|c|c|c|c|c|c|}
\hline & $\begin{array}{l}\text { PTC self- } \\
\text { heating }\end{array}$ & $36.4{ }^{\circ} \mathrm{C}$ & $\min$ & & temperature rate \\
\hline Lei et al. ${ }^{[49]}$ & $\begin{array}{l}\text { battery pack, } \\
\text { intermittent } \\
\text { self-heating }\end{array}$ & $\begin{array}{r}\text { heating for } \\
\text { stopping heatin } \\
\mathrm{s} \\
\text { last } 30\end{array}$ & $\begin{array}{l}.1 \mathrm{~s} \\
\text { for } 0.3\end{array}$ & $\Delta \mathrm{T}=2-3{ }^{\circ} \mathrm{C}$ & $\begin{array}{c}\text { good temperature } \\
\text { uniformity }\end{array}$ \\
\hline $\begin{array}{l}\text { Jiang et } \\
\text { al. }^{[50]}\end{array}$ & $\begin{array}{c}\text { battery cell, } \\
\text { direct current } \\
\text { and alternating } \\
\text { current }\end{array}$ & $\begin{array}{c}754 \mathrm{~Hz},- \\
20^{\circ} \mathrm{C}\end{array}$ & $\begin{array}{c}10 \\
\min \end{array}$ & $2.1^{\circ} \mathrm{C}$ & $\begin{array}{l}\text { the structure of } \\
\text { the heating device } \\
\text { is complex }\end{array}$ \\
\hline $\begin{array}{l}\text { Yang et } \\
\text { al. }{ }^{[51]}\end{array}$ & $\begin{array}{l}\text { battery pack, } \\
\text { an active } \\
\text { terminal added }\end{array}$ & $\begin{array}{l}\text { nickel foil } \\
\text { heating } \\
\text { elements } \\
\text { added }\end{array}$ & $10 \mathrm{~s}$ & $\begin{array}{l}\mathrm{T}_{\max }=50^{\circ} \mathrm{C} \\
\mathrm{T}_{\min }=-28^{\circ} \mathrm{C}\end{array}$ & $\begin{array}{c}\text { rapid temperature } \\
\text { rise } \\
\text { local overheating } \\
\text { poor temperature } \\
\text { uniformity }\end{array}$ \\
\hline $\begin{array}{c}\text { Ji and } \\
\text { Wang } \\
\text { [56] }\end{array}$ & $\begin{array}{c}\text { battery cell, } \\
\text { convection } \\
\text { heating }\end{array}$ & $60 \mathrm{~Hz},-20^{\circ} \mathrm{C}$ & $3 \min$ & $20^{\circ} \mathrm{C}$ & $\begin{array}{c}\text { rapid temperature } \\
\text { rise } \\
\text { Complex device } \\
\text { system }\end{array}$ \\
\hline
\end{tabular}

By comparing different heating methods of lithium-ion batteries, it can be found that the scholars have made contributions to ensuring the normal operation of LIBs of EVs at low temperatures from multiple perspectives, such as energy consumption, heating temperature, heating rate, temperature uniformity inside the battery, simplicity of heating device structure. Table 1 briefly summarizes the various heating methods used for LIBs. It can be found that the intermittent Self Heating LB (SHLB) method has the best temperature uniformity inside the LIBs, which is promising.

\section{Cooling methods for LIBs}

EV LIBs at high temperature must be cooled to augment the performance. Different methods have been proposed, including the air cooling, the liquid cooling and the PCM cooling technologies.

\subsection{Air cooling}

Air cooling is the most widely used heat dissipation method for battery packs, by directly using the wind around the moving car to conduct natural convection, or by generating forced airflow through the fan operation (Fig. 9). Natural convection has the obvious advantages of simplicity and low cost, while it also has the disadvantage of weak heat dissipation capacity due to uncontrollable wind. The forced convection by fan is more reliable and easier to maintain than the natural convection, therefore becoming a more common battery cooling method. However, a common problem for forced convection is the temperature uniformity within the cell. Researchers in various countries have conducted different optimizations to improve the temperature uniformity by taking the inconsistencies of the cell into account ${ }^{[62]}$. But due to the characteristics of air itself, its cooling 
effect has certain limitations.

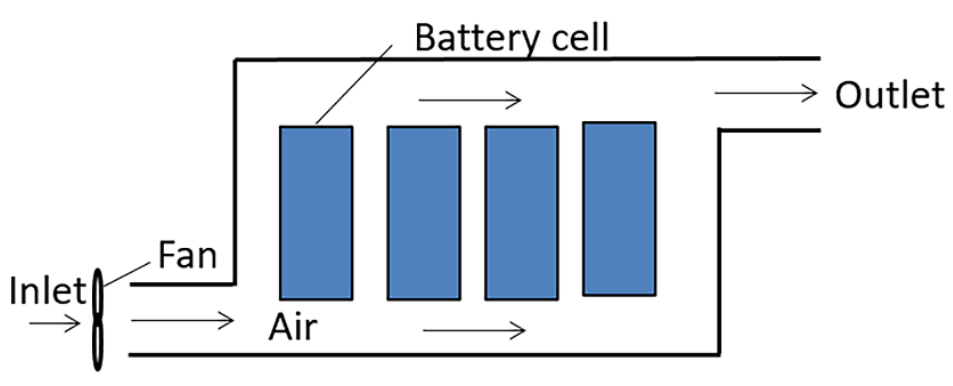

Fig. 9. Traditional Z-flow air cooling

Sun and Dixon ${ }^{[63]}$ have established a 3D battery pack thermal model based on the simplified electrode theory and combined with the experiments design model. It has been found that the geometric shape of the inlet and outlet channel plays an important role in the flow uniformity of the cooling channel, which significantly affects the temperature uniformity of LIBs. Based on the baseline z-type flow, the cooling surface area of the channel was increased by inserting ripples between the cooling plates in the battery pack (Fig. 10), thereby improving the temperature uniformity of the battery pack. The cooling efficiency of the flow channel can be increased to approximately $93 \%$.

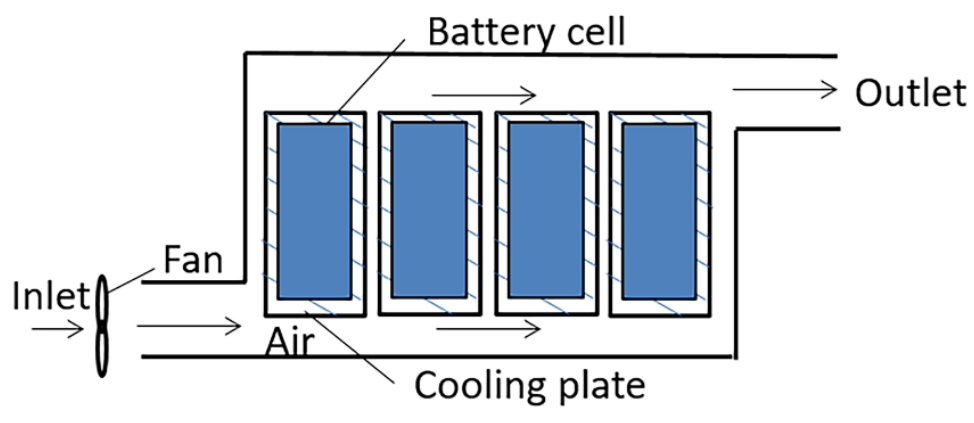

Fig. 10. Z-flow air cooling with corrugated sheets ${ }^{[63]}$

Chen et al. ${ }^{[64]}$ have improved the efficiency of the air-cooled BTMS by designing the air flow circuit. In their study, the influence of the location of the inlet and outlet areas on the cooling effect was examined (Fig. 11). Their numerical results showed that the symmetrical air-cooled cooling system with the inlet and outlet located in the middle of the static chamber had higher cooling efficiency than conventional Z-type flow circuit. Further experimental validation is still needed. 

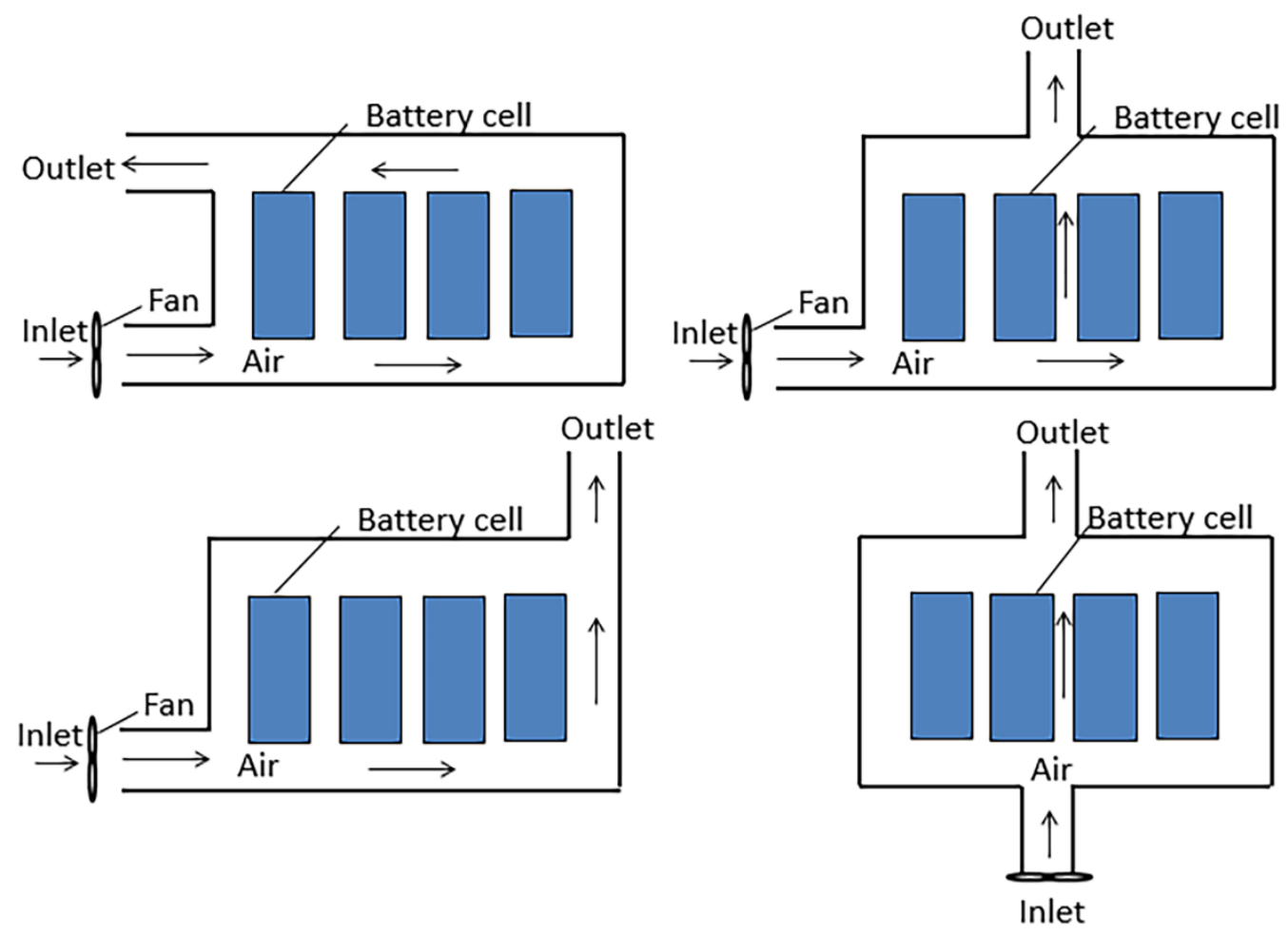

Fig. 11. Z-flow air cooling at different inlet and outlet locations ${ }^{[64]}$

Chekuri et al. ${ }^{[65]}$ have improved the temperature uniformity by using forced convection. The introduction of tapering inlet and outlet could reduce the battery temperature through 3D simulation of a LIB cooling system for hybrid cars. The optimization of conical inlet and outlet needs further study.

Behi et al ${ }^{[66]}$ have proposed a method of combining air cooling with heat pipe to improve the temperature uniformity of LIB. The experimental test and simulation verification of 24 cylindrical LIBs have shown that the new method could improve the battery temperature uniformity by about $70 \%$.

Xie et al. ${ }^{[67]}$ have proposed a novel design optimization method for air passage with varying cell spacing. Different air passages between each row and each column were used instead of evenly spaced air passages. The purpose is to reduce the resistance of the local channel and improve the uneven temperature of each cell in the battery pack. By optimizing the 3P4S battery pack (three strings in parallel and four cells in each string), the maximum temperature difference can be reduced by $2{ }^{\circ} \mathrm{C}$. However, for other combined forms of battery packs, optimization is still to be studied.

\subsection{Liquid cooling}

Liquid cooling is another commonly used method for the cooling of LIBs. Its principle is shown in Fig. 12. Compared with air cooling, liquid cooling is more efficient due to higher heat transfer coefficient of water ${ }^{[68]}$. Liquid cooling can be classified into direct cooling and indirect cooling. Direct cooling (such as liquid immersion cooling) can cool the entire battery surface, which greatly contributes to the temperature uniformity of LIBs. Direct contact liquid cooling ${ }^{[69-71]}$ is not common in automobile battery cooling system due to its high requirement on the waterproof 
performance of battery system, and electrical short circuit and electrochemical reaction may occur. Indirect liquid cooling (such as tube cooling, cold plate cooling with mini/micro channels, jacket cooling, etc.) has attracted the attention of many scholars due to its advantages of easier implementation and higher safety. The liquid cooling devices of cylindrical LIB ${ }^{[72-74]}$ and plate $\operatorname{LIB}^{[75,76]}$ have been proposed and studied. Usually, the cooling device is developed to be compact and light ${ }^{[77]}$, and new materials ${ }^{[78-80]}$ are used to improve the cooling channel. Preheating is also used for liquid cooling ${ }^{[81]}$. In addition, liquid cooling can also be combined with other methods such as air cooling ${ }^{[82]}$ or heat pipes ${ }^{[83]}$ to create better results. At present, most of the researches focus on the optimization of cooling plates through simulation or experimental methods ${ }^{[84-87]}$.

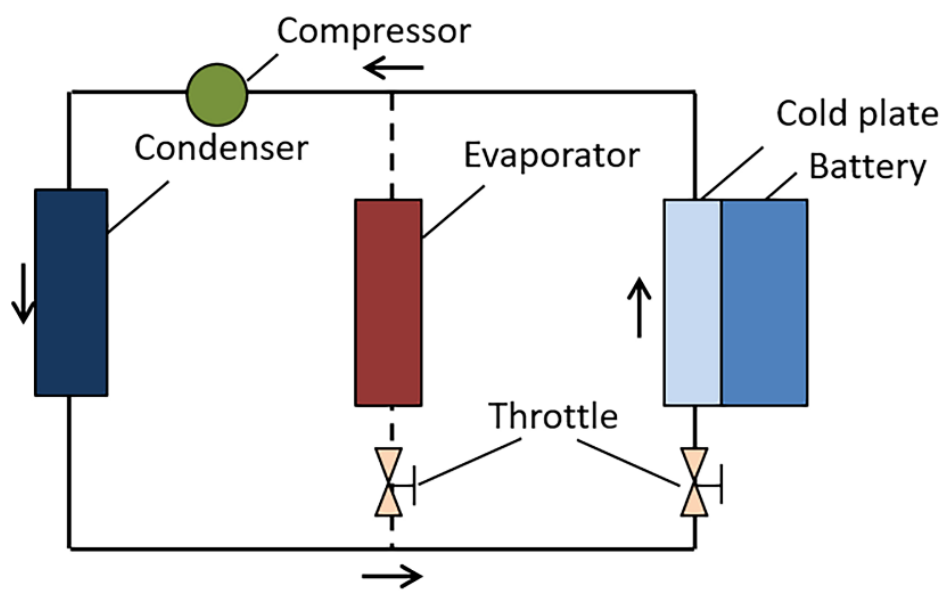

Fig. 12. Schematic of liquid cooling

Shen et al. ${ }^{[88]}$ have improved the air-conditioning system of traditional automobiles. A parallel plate (cold plate) was arranged on the evaporator side of the traditional automobile air conditioning system. After the refrigerant was throttled and decompressed in the expansion valve, it was directly introduced into the cooling pipe in the battery pack, and the battery directly exchanged heat with the refrigerant. The battery could be cooled from $44^{\circ} \mathrm{C}$ to about $30^{\circ} \mathrm{C}$. This kind of structure doesn't change much the initial structure of EVs, and the system is relatively simple. Compared with water cooling, the refrigerant has lower thermal conductivity, thus reducing the damage to the battery caused by coolant leakage. The efficiency of the experimental research system has a higher energy efficiency ratio, but there is still some room for improvement.

Mohammadian et al. ${ }^{[89]}$ have conducted a transient numerical simulation study to compare the internal and external cooling of LIBs. Internal cooling referred to the use of electrolyte as coolant to cool LIBs in the rectangular microchannels of positive and negative electrodes. External cooling referred to the cooling of LIBs with refrigerants through microchannels outside the cell. The maximum temperature and standard deviation of the internal temperature field did not decrease significantly by the external cooling. However, increasing the pumping power during internal cooling could significantly reduce the maximum temperature inside the battery and improve the temperature uniformity.

Jin et al. ${ }^{[90]}$ have designed an ultra-thin minichannel liquid cold plate (LCP) to improve the traditional straight channel LCP design. In conventional straight channel LCP designs, the development of the hydrodynamic boundary layer lead to the rise of the maximum temperature and a significant increase in the temperature gradient. The ultra-thin minichannel LCP redivided the 
boundary layer. The discontinuity of the downstream fins caused the hydrodynamic boundary layer to redevelop at the leading edge of the downstream segment. The inclined LCP was able to maintain the battery surface temperature below $50{ }^{\circ} \mathrm{C}$ under the condition of $1240 \mathrm{~W}$ and flow rate smaller than $0.9 \mathrm{~L} \mathrm{~min}^{-1}$. However, there was still some distance from the optimal working temperature of LIBs.

Darcovich et al. ${ }^{[91]}$ have made experimental measurements by selecting the smaller battery and used numerical simulations to compare two liquid-channel cooling plate structures, one for an ice plate (flush with battery face) placed between each cell of the battery pack and the other for a cold plate (bottom surface of battery) placed below the battery. Experiments and simulations showed that the vertical temperature difference existed in the cold plate system while the ice plate system generally performed better, allowing the battery to be cooled to $37^{\circ} \mathrm{C}$. But the ice disk system is relatively more complex. How to simplify the design and ensure the performance is particularly important in practical applications.

Zhen et al. ${ }^{[92]}$ have proposed a liquid cooling method based on micro-channel cold plate, A 3D numerical model of the method was established to analyze the influences of channel number, inlet mass flow, flow direction and channel width on the thermal performance of battery pack. The results showed that the mini-channel cold plate BTMS provided good cooling efficiency at $5 \mathrm{C}$ discharge. Increasing the number of channels and the mass flow at the inlet could reduce the maximum temperature and improve the temperature uniformity of LIBs.

Krüger et al. ${ }^{[93]}$ have studied the indirect evaporative cooling of automobile batteries under different climatic conditions using different refrigerants (R134a and R1234yf). But the energy consumption has been greatly affected by weather and driving cycle.

\subsection{PCM cooling}

PCM cooling method is similar to that of heating LIBs. Appropriate PCMs should be selected according to different requirements of phase change temperature. PCMs have the advantage of requiring no extra energy and the disadvantages of relatively complex cooling structures. Many scholars have carried out numerical simulation for the cooling method of PCM to improve its cooling uniformity ${ }^{[94-96]}$. The storage device of PCMs is also the research focus. Choudhari et al. ${ }^{[97]}$ have studied the influence of fin structure on the temperature uniformity of cylindrical LIBs. The structure of fin, battery and PCM is shown in Fig. 13. Simulation results showed that the i-shaped fins could have better heat transfer effect. Landini et al. ${ }^{[98]}$ have studied the influence of DirectMetal-Laser-Sintered aluminum heat exchangers on the temperature uniformity of battery. PCM cooling can also be combined with liquid cooling ${ }^{[99,100]}$ or heat pipes ${ }^{[101,102]}$ to achieve better cooling performance. 


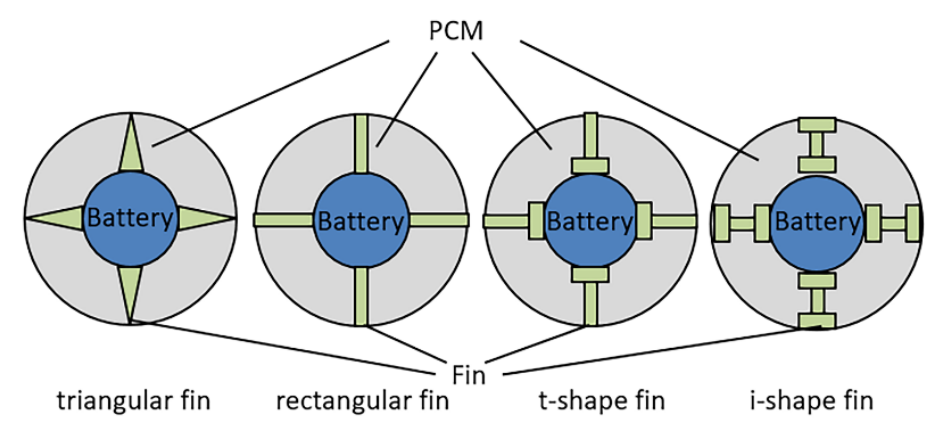

Fig. 13. The structure of fin, battery and $\mathrm{PCM}^{[97]}$

Bai et al. ${ }^{[103]}$ have designed the PCM/water-cooled plate battery module from the perspective of energy saving and fluid mechanics. The factors that affect the performance of the cooling module, such as the mass flow and flow direction of the inlet, thermal conductivity, PCM melting point, were analyzed numerically. The results showed that the PCM/water-cooled plate structure could effectively cool the LIBs. The average battery temperature could be maintained at $38.5^{\circ} \mathrm{C}$. But there was still a temperature difference of more than $10^{\circ} \mathrm{C}$ inside the battery pack.

Yu et al. ${ }^{[104]}$ have proposed a BTMS using PCMs and cooling water as the cooling device to control the temperature of LIBs. Specially, the graphite sheets were adopted to improve the thermal conductivity of the PCMs, leading to a better temperature uniformity. The effectiveness of this BTMS was verified by a 3D numerical simulation of LIB module. The maximum temperature difference could meet the demand only when 3 water cooling tubes worked together. A temperature difference of $6-8{ }^{\circ} \mathrm{C}$ still existed at both ends of the battery pack.

Lei et al. ${ }^{[105]}$ have proposed a BTMS integrating PCM, heat pipe and spray cooling, which can maintain the thermal stability of LIBs in different environment. A battery pack is formed by two LIBs connected in parallel, and a sintered copper-water heat pipe is sandwiched between them. The battery pack was placed in an acrylic box and the chamber was filled with PCM. The battery heat generated during the day would be stored in the PCM. When the battery temperature continued to rise, the battery heat would be transferred via a heat pipe from battery surfaces to its condensation end, and the water spray was carried out intermittently. When the temperature was cold at night, the latent heat stored in the PCM would be released, protecting LIB from low-temperature degradation in its performance and damages in its materials. The method could significantly improve the working temperature environment of LIBs, but the cooperation of multiple systems made the structure of the LIBs huge and complex.

\subsection{Short summary}

Table 2

Short summary of different cooling methods

\begin{tabular}{ccccc}
\hline Author & Method & Condition & Result & Notes \\
\hline bun and Dixon ${ }^{[63]}$ & $\begin{array}{c}\text { battery pack, } \\
\text { improve the cold } \\
\text { plate }\end{array}$ & $\begin{array}{c}\text { different } \\
\text { materials for } \\
\text { cold plate }\end{array}$ & $\begin{array}{c}\mathrm{T}_{\max }=33.8^{\circ} \mathrm{C} \\
\Delta \mathrm{T}=1.9{ }^{\circ} \mathrm{C}\end{array}$ & $\begin{array}{c}\mathrm{Z} \text { type corrugated } \\
\text { sheets better }\end{array}$ \\
Chen et al. ${ }^{[64]}$ & battery pack, & different & $\mathrm{T}_{\max }=55^{\circ} \mathrm{C}$ & in the middle of
\end{tabular}




\begin{tabular}{|c|c|c|c|c|}
\hline & $\begin{array}{l}\text { design the flow } \\
\text { pattern }\end{array}$ & $\begin{array}{l}\text { import and } \\
\text { export } \\
\text { locations }\end{array}$ & $\Delta \mathrm{T}=3.7^{\circ} \mathrm{C}$ & $\begin{array}{l}\text { the static chamber } \\
\text { better, with a } \\
\text { small temperature } \\
\text { difference }\end{array}$ \\
\hline Shen et al..$^{[88]}$ & $\begin{array}{l}\text { battery pack, } \\
\text { refrigeration-based } \\
\text { battery thermal } \\
\text { management }\end{array}$ & $\begin{array}{c}100 \mathrm{~km} / \mathrm{h} \\
\text { driving, } 700 \\
\mathrm{~s},\end{array}$ & $\begin{array}{l}50{ }^{\circ} \mathrm{C} \text { to } \\
30{ }^{\circ} \mathrm{C}\end{array}$ & $\begin{array}{c}\text { renovate the } \\
\text { original air } \\
\text { conditioning } \\
\text { system }\end{array}$ \\
\hline $\begin{array}{c}\text { Mohammadian et } \\
\text { al. }^{[89]}\end{array}$ & $\begin{array}{l}\text { battery cell, } \\
\text { liquid cooling }\end{array}$ & $\begin{array}{l}\text { Internal } \\
\text { cooling } \\
\text { external } \\
\text { cooling }\end{array}$ & $\begin{array}{c}\mathrm{T}_{\max }=35^{\circ} \mathrm{C} \\
\Delta \mathrm{T}=8{ }^{\circ} \mathrm{C} \\
\mathrm{T}_{\max }=42^{\circ} \mathrm{C} \\
\Delta \mathrm{T}=15^{\circ} \mathrm{C}\end{array}$ & $\begin{array}{l}\text { internal cooling } \\
\text { better, with a good } \\
\text { temperature } \\
\text { uniformity }\end{array}$ \\
\hline $\begin{array}{l}\text { Darcovich et } \\
\text { al. }{ }^{[91]}\end{array}$ & $\begin{array}{l}\text { battery cell, } \\
\text { liquid cooling }\end{array}$ & $\begin{array}{l}\text { ice plate } \\
\text { cooling } \\
\text { cold plate } \\
\text { cooling }\end{array}$ & $\begin{array}{c}\mathrm{T}_{\max }=31.6^{\circ} \mathrm{C} \\
\Delta \mathrm{T}=0.4^{\circ} \mathrm{C} \\
\mathrm{T}_{\max }=35^{\circ} \mathrm{C} \\
\Delta \mathrm{T}=5^{\circ} \mathrm{C}\end{array}$ & $\begin{array}{l}\text { ice plate cooling } \\
\text { better, system } \\
\text { complex }\end{array}$ \\
\hline Zhen et al. ${ }^{[92]}$ & $\begin{array}{c}\text { battery pack, } \\
\text { mini-channel cold } \\
\text { plate }\end{array}$ & $\begin{array}{l}\text { different } \\
\text { number of } \\
\text { mini- } \\
\text { channel }\end{array}$ & $\begin{array}{l}\mathrm{T}=40^{\circ} \mathrm{C} \\
\Delta \mathrm{T}=6^{\circ} \mathrm{C}\end{array}$ & $\begin{array}{c}\text { the more channels, } \\
\text { the better, up to } 5 \\
\text { channels }\end{array}$ \\
\hline Bai et al. ${ }^{[103]}$ & $\begin{array}{c}\text { battery pack, } \\
\text { PCM and cold plate }\end{array}$ & $\begin{array}{l}\text { different } \\
\text { height of the } \\
\text { cold plate }\end{array}$ & $\begin{array}{c}\mathrm{T}_{\max }=38.5^{\circ} \mathrm{C} \\
\Delta \mathrm{T}=10^{\circ} \mathrm{C}\end{array}$ & $\begin{array}{c}\mathrm{h}=5 \mathrm{~cm} \text { better } \\
\text { with a big vertical } \\
\text { temperature } \\
\text { difference }\end{array}$ \\
\hline Yu et al. ${ }^{[104]}$ & $\begin{array}{c}\text { battery pack, } \\
\text { PCM and cold plate }\end{array}$ & $\begin{array}{l}\text { different } \\
\text { number of } \\
\text { water } \\
\text { cooling } \\
\text { tubes }\end{array}$ & $\begin{array}{l}\mathrm{T}_{\max }=42^{\circ} \mathrm{C} \\
\Delta \mathrm{T}=5.6^{\circ} \mathrm{C}\end{array}$ & $\begin{array}{l}3 \text { water cooling } \\
\text { tubes better }\end{array}$ \\
\hline
\end{tabular}

It can be found that researchers have made contributions to ensuring the normal operation of LIBs of EVs at high temperatures from multiple perspectives, such as cooling temperature, cooling rate, temperature uniformity inside the battery, and the matching of cooling device with the air conditioning system of EVs. Table 2 provides a brief summary of commonly used cooling methods for LIBs. The combination of PCM and cold plate cooling method is promising. It can not only maintain the temperature of LIBs in the operating range, but also improve the temperature uniformity of the LIBs.

\section{Conclusion and prospects}

The problem of low/high temperature of LIB must be solved for the better development of EVs. Since EVs need to be used steadily throughout the year and the climate environment varies greatly in different regions, the working environment of LIBs for EVs is quite complex. A way to maintain the operating temperature of LIBs for all climates is particularly needed. In the current study, 
different methods proposed to improve the low temperature performance of LIBs have been summarized including the air heating, the liquid heating, the electric heating, the PCM heating and other heating methods. On the other hand, different methods have also been proposed to improve the high temperature performance of LIBs based on air cooling, liquid cooling and PCM cooling. The air heating/cooling method requires fans, air ducts and other accessories. The whole system is relatively large and the heat transfer efficiency is low. Liquid heating/cooling avoids the installation of the fan, air duct, but requires pumps, pipes and other accessories instead. The use of liquid greatly improves the heat transfer efficiency, but the liquid leakage is always a big risk. Electric heating is relatively simple and efficient, and therefore becomes the most common heating method. However, it may lead to uneven battery pack temperature and reduce its lifetime. In addition, PCMs are also a good choice for the thermal management of LIBs, for both winter heating and summer cooling if appropriate PCMs are employed.

A number of prospects could then be summarized as the directions of future research:

1. Adapted methods to maintain the stable and uniform temperature of the battery pack.

2. Compatible heating and cooling system of the battery with the air conditioning system of the vehicle, and the unified thermal management of the vehicle with rational use of resources.

3. Modification of the electrolyte of LIBs to change its electrolyte composition, so as to fundamentally improve the low-temperature performance of LIBs.

4. The aging effect of battery by the thermal management still needs to be studied.

\section{Acknowledgement}

This work is supported by the Key Research and Development (R\&D) Projects of Shanxi Province (201803D31035), the National Key Research and Development Program (Grant No.2016YFE0133300-04) and European project H2020-MSCA-RISE-2016: Low Energy Dew Point Cooling for Computing Data Centers (DEW-COOL-4CDC).

\section{List of abbreviations}

\begin{tabular}{ll}
\hline Abbreviation & Description \\
\hline BEV & Battery electric vehicle \\
BTMS & Battery thermal management system \\
CFD & Computational fluid dynamics \\
CPCM & Composite phase change material \\
EV & Electric vehicle \\
FCEV & Fuel cell electric vehicle \\
GHG & Greenhouse gasses \\
HEV & Hybrid electric vehicle \\
LCP & Liquid cold plate \\
LIB & Lithium-ion battery \\
PCM & Phase change material \\
PTC & Positive temperature coefficient \\
SHLB & Self-heating lithium-ion battery \\
\hline
\end{tabular}




\section{References}

1. Leman AM, Rahman F, Jajuli A, Zakaria S, Feriyanto D. Emission Treatment towards Cold Start and Back Pressure in Internal Combustion Engine against Performance of Catalytic Converter: A Review. MATEC Web of Conferences 2017; 87:02021.

2. Alptekin, Ertan. Emission, injection and combustion characteristics of biodiesel and oxygenated fuel blends in a common rail diesel engine. Energy 2017; 119(JAN.15):44-52.

3. Zhi C, Fang G. Preparation and heat transfer characteristics of microencapsulated phase change material slurry: A review. Renewable and Sustainable Energy Reviews 2011; 15(9):4624-4632.

4. Azam M, Khan AQ, Ozturk I. The effects of energy on investment, human health, environment and economic growth: empirical evidence from China. Environmental ence and Pollution Research 2019; 26(11):10816-10825.

5. Huang Z, Hao C, J W. Analysis Of Vehicle Contaminants Emission in China. Environmental Protection 2017; (13):42-47.

6. Fu-qiang A, Hong-liang Z, Zhi C, Yi-cheng QJ, Wei-nan Z, Ping L. Development status and research progress of power battery for pure electric vehicles. Chinese Journal of Engineering 2019; 41(01):2545.

7. Chen Q, Sun F, Zhu J. Modern electric vehicle technology. Beijing Institute of Technology Press; 2002.

8. Xue-Jie H. Electric vehicles and Li-ion batteries. Physics 2015; 44(1):1-7.

9. Tarascon JM, Armand M. Issues and challenges facing rechargeable lithium batteries. Nature 2001; 414(6861):359-367.

10. Nitta N, Wu F, Lee JT, Yushin G. Li ion Battery Materials: Present and Future. Materials Today 2014; 18(5):252-264.

11. Jaguemont J, Boulon L, Dubé Y. A comprehensive review of lithium-ion batteries used in hybrid and electric vehicles at cold temperatures. Applied Energy 2016; 164:99-114.

12. Aneke M, Wang M. Energy storage technologies and real life applications - A state of the art review. Applied Energy 2016; 179:350-377.

13. Basu S, Hariharan KS, Kolake SM, Song T, Sohn DK, Yeo T. Coupled electrochemical thermal modelling of a novel Li-ion battery pack thermal management system. Applied Energy 2016; 181:113.

14. Zhang X, Kong X, Li G, Li J. Thermodynamic assessment of active cooling/heating methods for lithium-ion batteries of electric vehicles in extreme conditions. Energy 2014; 64:1092-1101.

15. Huang C-K, Sakamoto JS, Wolfenstine J, Surampudi S. The limits of low temperature performance of Li-ion cells. Journal of The Electrochemical Society 2000; 17(8):2893-2896.

16. Cen J, Li Z, Jiang F. Experimental investigation on using the electric vehicle air conditioning system for lithium-ion battery thermal management. Energy for Sustainable Development 2018; 45:88-95.

17. Raijmakers LHJ, Danilov DL, Eichel RA, Notten PHL. A review on various temperatureindication methods for Li-ion batteries. Applied Energy 2019; 240(APR.15):918-945.

18. Xie. Y, Li. W , Hu. X , Zou. C, f F. Novel Mesoscale Electrothermal Modeling for Lithium-Ion Batteries. IEEE Transactions on Power Electronics 2020; 35(3):2595-2614.

19. Xie Y, Li W, Hu X, Lin X, Yue H. An Enhanced Online Temperature Estimation for Lithium-Ion Batteries. IEEE Transactions on Transportation Electrification 2020; 6(2):375-390. 
20. Wu S, Xiong R, Li H, Nian V, Ma S. The state of the art on preheating lithium-ion batteries in cold weather. Journal of Energy Storage 2020; 27(Feb.):101059.101051-101059.101013.

21. Vidal C, Gross O, Gu R, Kollmeyer P, Emadi A. XEV LI-ION BATTERY LOW TEMPERATURE EFFECTS - REVIEW. IEEE Transactions on Vehicular Technology 2019; 68(5):4560-4572.

22. Jaguemont J, Mierlo JV. A comprehensive review of future thermal management systems for battery-electrified vehicles. The Journal of Energy Storage 2020; 31:101551.

23. Landini S, Leworthy J, O'Donovan TS. A Review of Phase Change Materials for the Thermal Management and Isothermalisation of Lithium-Ion Cells. Journal of Energy Storage 2019; 25(Oct.):100887.100881-100887.100839.

24. Chen J, Kang S, Jiaqiang E, Huang Z, Liao G. Effects of different phase change material thermal management strategies on the cooling performance of the power lithium ion batteries: A review. Journal of Power Sources 2019; 442:227228.

25. Solyali D, Akinlabi AHA. Configuration, design, and optimization of air-cooled battery thermal management system for electric vehicles: A review. Renewable and Sustainable Energy Reviews 2020; 125:109815.

26. Choudhari VG, Dhoble DAS, Sathe TM. A review on effect of heat generation and various thermal management systems for lithium ion battery used for electric vehicle. The Journal of Energy Storage 2020; 32:101729.

27. Padhi AAK, Nanjundaswamy KS, Goodenough JBD. Phospho-Olivines as Positive-Electrode Materials for Rechargeable Lithium Batteries. Journal of The Electrochemical Society 1997; 144(4):1188-1194.

28. Saito Y, Kanari K, Takano K. Thermal studies of a lithium-ion battery. Journal of Power Sources 1997; 68(2):451-454.

29. Wang Q, Jiang B, Li B, Yan Y. A critical review of thermal management models and solutions of lithium-ion batteries for the development of pure electric vehicles. Renewable and Sustainable Energy Reviews 2016; 64:106-128.

30. Alkhulaifi YM, Qasem NAA, Zubair SM. Improving the performance of thermal management system for electric and hybrid electric vehicles by adding an ejector. Energy Conversion and Management 2019; 201.

31. Zhang C, Jiang J, Gao Y, Zhang W, Liu Q, Hu X. Charging optimization in lithium-ion batteries based on temperature rise and charge time. Applied Energy 2017; 194.

32. Jaguemont J, Boulon L, Dubé Y, Martel F. Thermal Management of a Hybrid Electric Vehicle in Cold Weather. IEEE Transactions on Energy Conversion 2016; 31(3):1110-1120.

33. Yu-tao H, Zhong-hao R, Jia-teng Z, Chen-zhen L. Research Development of Battery Thermal Management at Low Temperature. Advances in New and Renewable Energy 2015; 3(01):53-58.

34. Lei Z, Zhang C, Li J, Fan G, Lin Z. A study on the low-temperature performance of lithium-ion battery for electric vehicles. Automotive Engineering 2013; 35(10):927-933.

35. Rao Z, Wang S. A review of power battery thermal energy management. Renewable and Sustainable Energy Reviews 2011; 15(9):4554-4571.

36. Chen $\mathrm{Z}$, Xiong $\mathrm{R}$, Lu J, Li X. Temperature rise prediction of lithium-ion battery suffering external short circuit for all-climate electric vehicles application. Applied Energy 2018; 213:375-383. 37. Joris DH, Joris J, Mohamed AM, Peter VDB, Joeri VM, Noshin O. Combining an Electrothermal and Impedance Aging Model to Investigate Thermal Degradation Caused by Fast Charging. Energies 2018; 11(4):804. 
38. Ouyang D, Chen M, Huang Q, Weng J, Wang J. A Review on the Thermal Hazards of the LithiumIon Battery and the Corresponding Countermeasures. Applied Sciences 2019; 9(12):2483-2528.

39. Xiaoqing Z, Zhenpo W, Hsin W, Cong W. Review of Thermal Runaway and Safety Management for Lithium-ion Traction Batteries in Electric Vehicles. Journal of Mechanical Engineering 2020; 56(14):91-118.

40. De Santoli L, Paiolo R, Lo Basso G. An overview on safety issues related to hydrogen and methane blend applications in domestic and industrial use. Energy Procedia 2017; 126:297-304.

41. Wu W, Wang S, Chen K, Hong S, Lai Y. A critical review of battery thermal performance and liquid based battery thermal management. Energy Conversion and Management

2019; 182:262-281.

42. Lei Z, Maotao Z, Xiaoming X, Junkui G. Thermal runaway characteristics on NCM lithium-ion batteries triggered by local heating under different heat dissipation conditions. Applied Thermal Engineering 2019; 159:113847.

43. Al-Zareer M, Dincer I, Rosen MA. A novel approach for performance improvement of liquid to vapor based battery cooling systems. Energy Conversion and Management 2019; 187:191-204.

44. Al-Zareer M, Dincer I, Rosen MA. A novel phase change based cooling system for prismatic lithium ion batteries. International Journal of Refrigeration 2017; 86:203-217.

45. Li J, Wu P, Tian H. Researches on heating low-temperature lithium-ion power battery in electric vehicles. In: 2014 IEEE Transportation Electrification Conference and Expo, Asia-Pacific ITEC AsiaPacific: IEEE; 2014.

46. LEI Z, Chengning ZHANG, LI J, FAN G, LIN Z. Preheating method of lithium-ion batteries in an electric vehicle. Journal of Modern Power Systems \& Clean Energy 2015; 3(2):289-296.

47. J J, Boulon L, Dubé Y. Characterization and Modeling of a Hybrid-Electric-Vehicle LithiumIon Battery Pack at Low Temperatures. IEEE Transactions on Vehicular Technology 2016; 65(1):114.

48. Xin, Jin, Jun-qiu, Li, Chen-ning, Zhang, et al. Researches on Modeling and Experiment of Li-ion Battery PTC Self-heating in Electric Vehicles. Energy Procedia 2016; 104:62-67.

49. Lei Z, Zhang Y, Lei X. Improving temperature uniformity of a lithium-ion battery by intermittent heating method in cold climate. International Journal of Heat \& Mass Transfer 2018; 121:275-281.

50. Jiang J, Ruan H, Sun B, Wang L, Gao W, Zhang W. A low-temperature internal heating strategy without lifetime reduction for large-size automotive lithium-ion battery pack. Applied Energy 2018; 230:257-266.

51. Yang X-G, Liu T, Wang C-Y. Innovative heating of large-size automotive Li-ion cells. Journal of Power Sources 2017; 342:598-604.

52. Wang CY, Zhang G, Ge S, Xu T, Leng Y. Lithium-ion battery structure that self-heats at low temperatures. Nature 2016; 529(7587):515.

53. Zhang G, Tian H, Ge S, Marple D, Sun F, Wang C-Y. Visualization of self-heating of an all climate battery by infrared thermography. Journal of Power Sources 2018; 376:111-116.

54. Yang XG, Guangsheng Z, Shanhai G, Chao-Yang W. Fast charging of lithium-ion batteries at all temperatures. Proceedings of the National Academy of Sciences of the United States of America 2018:201807115-.

55. Yang XG, Zhang G, Wang C-Y. Computational design and refinement of self-heating lithium ion batteries. Journal of Power Sources 2016; 328:203-211. 
56. Ji Y, Wang CY. Heating strategies for Li-ion batteries operated from subzero temperatures. Electrochimica Acta 2013; 107:664-674.

57. Mahamud R, Park C. Reciprocating air flow for Li-ion battery thermal management to improve temperature uniformity. Journal of Power Sources 2011; 196(13):5685-5696.

58. Xia G, Cao L, Bi G. A review on battery thermal management in electric vehicle application. Journal of Power Sources 2017; 367:90-105.

59. Nelson P, Dees D, Amine K, Henriksen G. Modeling thermal management of lithium-ion PNGV batteries. Journal of Power Sources 2002; 110(2):349-356.

60. Troxler Y, Wu B, Marinescu M, Yufit V, Patel Y, Marquis AJ, et al. The effect of thermal gradients on the performance of lithium-ion batteries. Journal of Power Sources 2014; 247:1018-1025.

61. Parekh BK. Development and Evaluation of Active Thermal Management System for LithiumIon Batteries using Solid-State Thermoelectric Heat Pump and Heat Pipes with Electric Vehicular Applications. Dissertations \& Theses - Gradworks 2015.

62. Peng X, Ma C, Garg A, Bao N, Liao X. Thermal performance investigation of an air-cooled lithium-ion battery pack considering the inconsistency of battery cells. Applied Thermal Engineering 2019; 153:596-603.

63. Sun H, Dixon R. Development of cooling strategy for an air cooled lithium-ion battery pack. Journal of Power Sources 2014; 272:404-414.

64. Chen K, Wu W, Yuan F, Chen L, Wang S. Cooling efficiency improvement of air-cooled battery thermal management system through designing the flow pattern. Energy 2019; 167:781-790.

65. Chekuri BG, Vaskuri PSS, Chary SSK, Thundil RRKJICSE, Science E. Three dimensional numerical validation and investigation on air cooling system of Li-ion battery used in hybrid electric vehicles. IOP Conference Series Earth and Environmental Science 2019; 312.

66. Behi H, Karimi D, Behi R, Ghanbarpour M, Mierlo JV. A new concept of thermal management system in Li-ion battery using air cooling and heat pipe for electric vehicles. Applied Thermal Engineering 2020; 174:115280.

67. Xie Y, Li B, Hu X, Lin X, Zheng J. Improving the Air-Cooling Performance for Battery Packs via Electro-Thermal Modelling and Particle Swarm Optimization. IEEE Transactions on Transportation Electrification 2020:1-16.

68. Kim J, Oh J, Lee H. Review on battery thermal management system for electric vehicles. Applied Thermal Engineering 2019; 149:192-212.

69. Dincer I, Hamut HS, Javani N. Thermal Management of Electric Vehicle Battery Systems. 2017; 10.1002/9781118900239:445-457.

70. Xia G, Cao L, Bi G. A review on battery thermal management in electric vehicle application. Journal of Power Sources 2017; 367(nov.1):90-105.

71. Yang S, Yang S, Ling C, Fan Y, Yang Y, Tan X, et al. A Review of Lithium-Ion Battery Thermal Management System Strategies and the Evaluate Criteria. International Journal of Electrochemical Science 2019; 14:6077-6107.

72. Yates M, Akrami M, Javadi AAJTJoES. Analysing the performance of liquid cooling designs in cylindrical lithium- ion batteries. The Journal of Energy Storage 2019:100913.

73. Hu X, Liu W, Lin X, Xie Y. A Comparative Study of Control-Oriented Thermal Models for Cylindrical Li-Ion Batteries. IEEE Transactions on Transportation Electrification 2019; 5(4):12371253.

74. Tang Z, Wang S, Liu Z, Cheng J. Numerical analysis of temperature uniformity of a liquid cooling 
battery module composed of heat-conducting blocks with gradient contact surface angles. Applied Thermal Engineering 2020; 178:115509.

75. Li M, Wang J, Guo Q, Li Y, Qin G. Numerical Analysis of Cooling Plates with Different Structures for Electric Vehicle Battery Thermal Management Systems. Journal of Energy Engineering 2020; 146(4):04020037.

76. Xie Y, Zheng J, Hu X, Lin X, Feng F. An improved resistance-based thermal model for prismatic lithium-ion battery charging. Applied Thermal Engineering 2020; 180(11):115794.

77. A YL, A WW, A KC, A SW, B CX. A compact and lightweight liquid-cooled thermal management solution for cylindrical lithium-ion power battery pack. International Journal of Heat and Mass Transfer 2019; 144:118581.

78. Boháek J, Raudensky M, Kroulikova T, Karimi-Sibaki E. Polymeric hollow fibers: A supercompact cooling of Li-ion cells. International Journal of Thermal Sciences 2019; 146:106060.

79. Bohacek J, Raudensky M, Karimi-Sibaki E. Polymeric hollow fibers: Uniform temperature of Liion cells in battery modules. Applied Thermal Engineering 2019; 159:113940.

80. Yang W, Zhou F, Zhou H, Liu Y. Thermal performance of axial air cooling system with bionic surface structure for cylindrical lithium-ion battery module. International Journal of Heat and Mass Transfer 2020; 161:120307.

81. Vu H, Shin D. Scheduled Pre-Heating of Li-Ion Battery Packs for Balanced Temperature and State-of-Charge Distribution. Energies 2020; 13(9):2212.

82. Yang W, Zhou F, Zhou H, Wang Q, Kong J. Thermal performance of cylindrical Lithium-ion battery thermal management system integrated with mini-channel liquid cooling and air cooling. Applied Thermal Engineering 2020; 175:115331.

83. Zhang C, Xia Z, Wang B, Gao H, Chen S, Zong S, et al. A Li-Ion Battery Thermal Management System Combining a Heat Pipe and Thermoelectric Cooler. Energies 2020; 13(4):841-856.

84. Wang C, Zhang G, Li X, Huang J, Wang Z, Lv Y, et al. Experimental examination of large capacity liFePO4 battery pack at high temperature and rapid discharge using novel liquid cooling strategy. International Journal of Energy Research 2018; 42(3):1172-1182.

85. Du X, Qian Z, Chen Z, Rao Z. Experimental investigation on mini-channel cooling-based thermal management for Li-ion battery module under different cooling schemes. International Journal of Energy Research 2018; 42(15):2781-2788.

86. Jiaqiang E, ., Han D, Qiu A, Zhu H, Deng Y, Chen J, et al. Orthogonal experimental design of liquid-cooling structure on the cooling effect of a liquid-cooled battery thermal management system. Applied Thermal Engineering 2018; 132:508-520.

87. Chen S, Peng X, Bao N, Garg A. A comprehensive analysis and optimization process for an integrated liquid cooling plate for a prismatic lithium-ion battery module - ScienceDirect. Applied Thermal Engineering 2019; 156:324-339.

88. Ming S, Qing G, Yan W, Tian-shi Z. Design and analysis of battery thermal management system for electric vehicle. Journal of Zhejiang University (Engineering Science) 2019; 53(7):1398-1406.

89. Mohammadian SK, He YL, Zhang Y. Internal cooling of a lithium-ion battery using electrolyte as coolant through microchannels embedded inside the electrodes. Journal of Power Sources 2015; 293:458-466.

90. Jin LW, Lee PS, Kong XX, Fan Y, Chou SK. Ultra-thin minichannel LCP for EV battery thermal management. Applied Energy 2014; 113:1786-1794.

91. Darcovich K, MacNeil DD, Recoskie S, Cadic Q, Ilinca F. Comparison of Cooling Plate 
Configurations for Automotive Battery Pack Thermal Management. Applied Thermal Engineering 2019; 155:185-195.

92. Zhen Q, Li Y, Rao Z. Thermal performance of lithium-ion battery thermal management system by using mini-channel cooling. Energy Conversion \& Management 2016; 126:622-631.

93. Krüger IL, Limperich D, Schmitz G. Energy Consumption Of Battery Cooling In Hybrid Electric Vehicles. International Refrigeration and Air Conditioning Conference 2012:2334-2344.

94. Mohammad Parhizi, Jain A. Analytical Modeling and Optimization of Phase Change Thermal Management of a Li-ion Battery Pack. Applied Thermal Engineering 2018; 148:229-237.

95. Cao J, Ling Z, Fang X, Zhang Z. Delayed liquid cooling strategy with phase change material to achieve high temperature uniformity of Li-ion battery under high-rate discharge. Journal of Power Sources 2020; 450:227673.

96. Hong SH, Jang DS, Park S, Yun S, Kim Y. Thermal performance of direct two-phase refrigerant cooling for lithium-ion batteries in electric vehicles. Applied Thermal Engineering 2020; 173:115213. 97. Choudhari VG, Dhoble AS, Panchal S. Numerical analysis of different fin structures in phase change material module for battery thermal management system and its optimization ScienceDirect. International Journal of Heat and Mass Transfer 2020; 163:120434.

98. Landini S, Waser R, Stamatiou A, Ravotti R, O'Donovan TS. Passive Cooling of Li-Ion Cells with Direct-Metal-Laser-Sintered Aluminium Heat Exchangers filled with Phase Change Materials. Applied Thermal Engineering 2020:115238.

99. Cao J, Luo M, Fang X, Ling Z, Zhang Z. Liquid cooling with phase change materials for cylindrical Li-ion batteries: An experimental and numerical study. Energy 2020; 191:116565.

100. Hekmat S, Molaeimanesh GR. Hybrid thermal management of a Li-ion battery module with phase change material and cooling water pipes: An experimental investigation. Applied Thermal Engineering 2020; 166.

101. Putra N, Sandi AF, A BA, A NA, Mahlia TMI. Performance of beeswax phase change material (PCM) and heat pipe as passive battery cooling system for electric vehicles - ScienceDirect. Case Studies in Thermal Engineering 2020; 21:100655.

102. Jiang ZY, Qu ZG. Lithium-ion battery thermal management using heat pipe and phase change material during discharge-charge cycle: A comprehensive numerical study. Applied Energy 2019; 242:378-392.

103. Bai F, Chen M, Song W, Feng Z, Li Y, Ding Y. Thermal management performances of PCM/water cooling-plate using for lithium-ion battery module based on non-uniform internal heat source. Applied Thermal Engineering 2017; 126:17-27.

104. Yu GY, Chiang SW, Chen W, Du HD. Thermal Management of a Li-Ion Battery for Electric Vehicles Using PCM and Water-Cooling Board. Key Engineering Materials 2019; 814:307-313.

105. Lei S, Shi Y, Chen G. A lithium-ion battery-thermal-management design based on phasechange-material thermal storage and spray cooling. Applied Thermal Engineering 2019; 168:114792. 